\title{
Social Responsibility: a look to the challenges faced by an university and a leather goods company, in Bogota, Colombia
}

\author{
La Responsabilidad Social: una mirada desde los retos que tienen una institución de educación \\ superior y una empresa del sector marroquinero, en Bogotá Colombia \\ Sandra P.Restrepo-Collazos ${ }^{a}$, Camilo A.Castaño-Martínez ${ }^{b}$
}

\begin{abstract}
:
The objective of this research is to give a perception from social responsibility in two economic sectors: business and education, in terms of the challenges presented by leather companies and universities in the city of Bogota Colombia, relating both, corporate social responsibility and education. The following research was carried out using a qualitative method, based on a theoretical design, with an in-depth interview technique and sampling for convenience. For the analysis of qualitative data, the tool used was the Atlas ti software, where the categories of analysis and semantic networks emerge. The analysis units studied were: a nationally and internationally recognized leather company and the University. As a result, the two analysis units highlight the importance that CSR and RSU should have in the actions towards people, students, society and the environment
\end{abstract}

Keywords:

Corporate Social Responsibility, University Social Responsibility

\section{Resumen:}

El objetivo de esta investigación es dar una mirada desde la responsabilidad social a dos sectores: el empresarial y educativo, en cuanto a los retos que presenta las empresas de marroquinería y las universidades en la ciudad de Bogotá Colombia, relacionando la responsabilidad social empresarial y educativa respectivamente. La siguiente investigación se realizó con método cualitativo, diseño teoría fundamentada, con técnica entrevista en profundidad y muestreo por conveniencia. Para el análisis de datos cualitativos, se utilizó la herramienta del software Atlas ti, donde surgen las categorías de análisis y redes semánticas. Las unidades de análisis estudiadas son: una empresa marroquinera reconocida a nivel nacional e internacional y una Instituciones de Educación Superior (IES). Como resultado se destaca en las dos unidades de análisis, la importancia que la RSE y la RSU, debe tener en las acciones hacia las personas, estudiantes, la sociedad, y el medio ambiente.

\section{Palabras Clave:}

Responsabilidad Social Empresarial, Responsabilidad Social Universitaria

\section{Introduction}

Corporate Social Responsibility (CSR) and University Social Responsibility (USR) contribute to the well-being of people, and highlight from theoretical concepts how those are carried into practice by the company and by the university. On the other hand, make readers aware of a current view on (USR) and (CSR) in the city of Bogotá and, in this way, show the foreseeable future of the organizations.
It is evident that both CSR and USR assist organizations and educational institutions to be more strategic in establishing excellent relationships with their stakeholders. This begs the question: How do a university and a leather goods company located in the city of Bogota, Colombia, contribute to the integral development of the people who make them up, from the point of view of University Social Responsibility and Corporate Social Responsibility? [1]

\footnotetext{
${ }^{a}$ Psychology professor Minuto de Dios University, Bogotá, Colombia. Orcid, https://orcid.org/0000-0002-1126-121X

PhD student in Administration, Celaya University, Guanajuato, México. sandra.restrepo.co@uniminuto.edu.co17011903@udec.edu.mx

${ }^{\mathrm{b}}$ Economics professor Santo Tomás University, Bogotá, Colombia. Orcid, https://orcid.org/0000-0002-7983-8417

PhD student in Administration, Celaya University, Guanajuato, México. camilocastano@ustadistancia.edu.co17011873@udec.edu.mx
} 


\section{State of the art}

In the 70s, companies were focused on obtaining profits without taking into account the environmental or social elements, only the economic. The only social responsibility of businesses was to increase its profits. [4]

Subsequently, with the Stakeholders model generated a different approach to business management, it started from the various groups to which the company would have certain social responsibilities; this broke the paradigm that the company should only be managed according to the interests of the shareholders, since besides them, there were many other interested parties (affected by the organisation's performance and the achievement of stakeholders) with a legitimate interest in the business, and that could affect the objectives. [2]

Years later, the triple baseline model emerged 1, based on the idea that businesses do not have the sole objective of creating economic value, but that this should be expanded to also include the generation of social and environmental value and thus achieve long-term business sustainability.

The discussion turned to the strategic CSR, understood not as an expense, a remuneration or a charity, but as a source of innovation and competitive advantage, by aligning CSR actions with business strategy. For this, it is necessary for companies to analyze the issue of social responsibility under the same parameters with which they make decisions in their main business; that they identify the economic, social and environmental impacts of their actions (Sustainable Development); that they discover opportunities to generate tangible benefits to their stakeholders and those same stakeholders through the strengthening of the competitive environment in which they operate.

The competitiveness of companies is only achieved in a competitive and favourable environment at the same time. The following question emerged What should be the role of companies in creating and supporting these environments? The answer is emphatic: for companies seeking to increase their competitiveness it is very strategically important to support the sustainable development of their environment. Only if there is an adequate environment, good levels of education, a trained workforce, a healthy environment, functional communities, high levels of health coverage, etc., it will be true to say that there is an economy with sustainable competitiveness.[8]

In Latin America, one can find that in different parts of the continent several universities have started to develop USR since 2000-2010. Mexico is the country where most initiatives have been developed. Based on the review of the specialized documents, the following characteristics are observed: Each university has a particular definition of USR, the institutions apply USR differently and place greater emphasis on one aspect than on others, especially in relation to the environment and social impact, the evaluation methods are carried out by the institution itself, the majority are quantitative and are in the process of being constructed. These variables are taken into account when applying and evaluating RSU: type of public or private financing, type of professional or technical training, budget, estimated time to observe the impact and measure it since it was implemented, scale of coverage, municipal, regional, national, number of students, teachers and administrative workers. These are some of the definitions found in universities in different Latin American countries, each one reflecting the variables listed above. [10]

One of the factors that are analyzed by RSU specialists is quality; in Colombia, the Ministry of Education describes quality, based on the Quality Project Evaluation, certification and accreditation as: A Project aimed at consolidating the quality assurance system in higher education through actions focused on the evaluation of institutions and higher education programs for: the granting of the Qualified Registration, authorization for the educational offer; the High Quality Accreditation of programs and institutions, as recognition of the excellence of the offer; and the Validation of degrees obtained abroad. It also includes activities aimed at restructuring and applying the SABER PRO higher education tests and the participation of an international study, which will show the development of generic competences. [7]

\section{Development}

The instruments designed for the research correspond to 12 questions in the CSR-oriented research and 10 questions in the RSU research, from which one question each was taken for the presentation of this paper.

The data has been collected in 2019 for CSR and 2020 for RSU. The selection of the participating universities and employers is due to the relevance of the research, which seeks to include all the components that are reproduced through the relevant discourses and behaviors, relationships and knowledge. [5]. Hence the sample is selective, few cases can be suitable since what is important is the depth and not the quantity, nor the numerical representation of participants in the research. After the application of the interviews, the data were systematized using the Atlas.ti software for qualitative analysis of textual data. [5]

In relation to figure 1 , it shows how the analysis of the interviews will be carried out for the representatives of the two sectors, where Quality in the Company and Quality in higher education were taken as axes of investigation, at the same time Responsibility for the Organizations and Responsibility for the entities of higher education, framed in the Family "Social Responsibility".

\section{Figure 1. Social Responsibility}

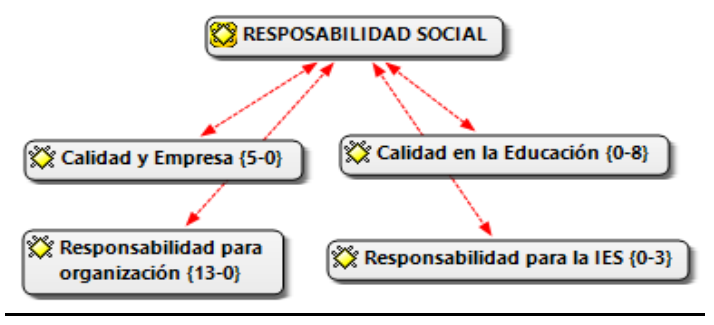

Authors 2020. 
As for the research axis "Quality for the company", which corresponds to figure 2 , the entrepreneur refers to the fact that the most important premise is to put love into what one does. Part of the quality in their products and their organization is that direct distribution is carried out without intermediaries. What makes it different from other companies in the sector is that thanks to their passion for their work, they are perceived as having a quality that identifies them and makes them a unique company in Latin America, due to the brand that has been built up over 40 years in the market.

Figure 2. Quality for the company.

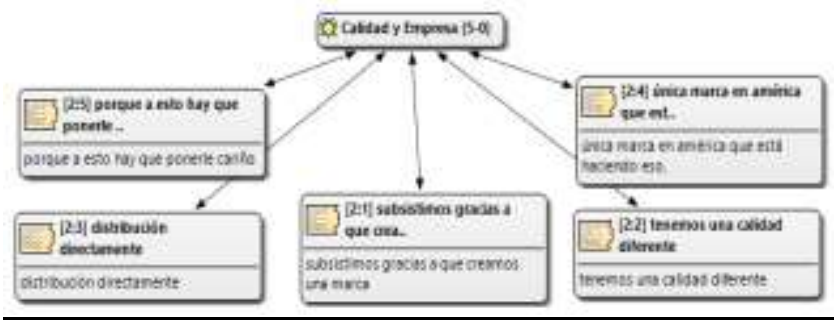

Authors 2020.

With the axis of research Quality for Higher Education Institutions in Figure 3, it is clear that the most important profession is that of the educator, who is responsible for developing much more humane and environmentally conscious people. On the other hand, to work on the creation of new public policies that lead the student population to unrestricted connectivity. As far as institutions are concerned, they must work on making the curriculum more flexible and bear in mind that flexibility does not go against quality, and thus be in the vanguard and aligned with the requirements of the organizations.

Figure 3. Quality for Higher Education Institutions. Authors 2020

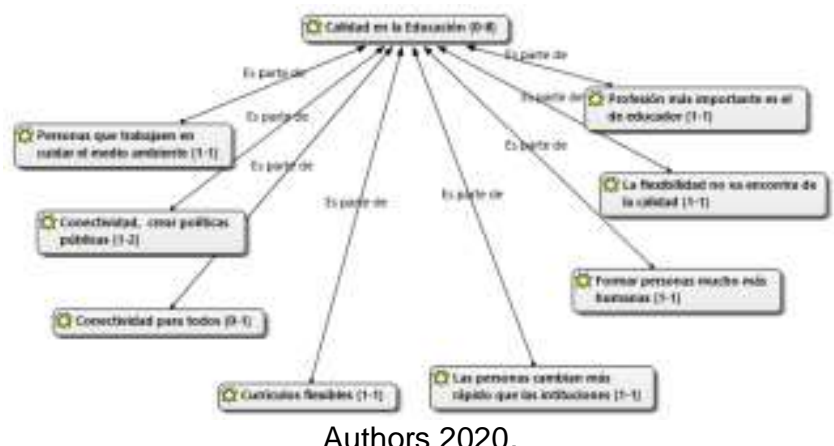

As evidenced in figure 4, "Social Responsibility for the organization", its employees have been with the company for between 5 and 30 years, which demonstrates the job stability offered to those who are part of the company. As the employer says, one must "put love" with an excellent treatment to people, providing them with training, where they enter as apprentices and leave as expert master craftsmen. At the same time, the company makes important efforts to ensure that employees can have their own home after three years of service. It is worth noting the importance of having an open-door organization where the most relevant are the people who collaborate with the company.
Figure 4. Social Responsibility for the organization.

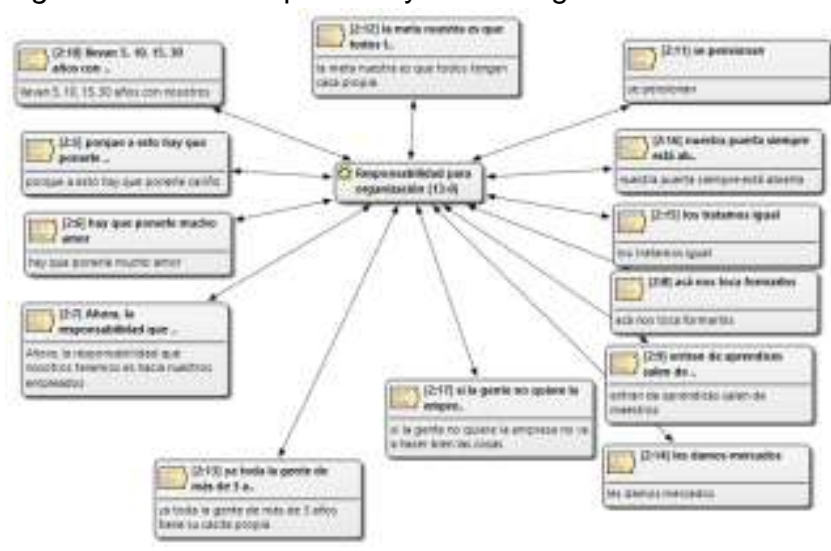

Authors 2020.

Finally, in Figure 5, which corresponds to the axis of inquiry "Social Responsibility", work should be done in the near future on the soft skills of students, so as not to lose the most important factor the university rector refers to, which is the human factor. The current situation in the world has led society to become more resilient and thus much more supportive and cooperative.

Figure 5. Social Responsibility.

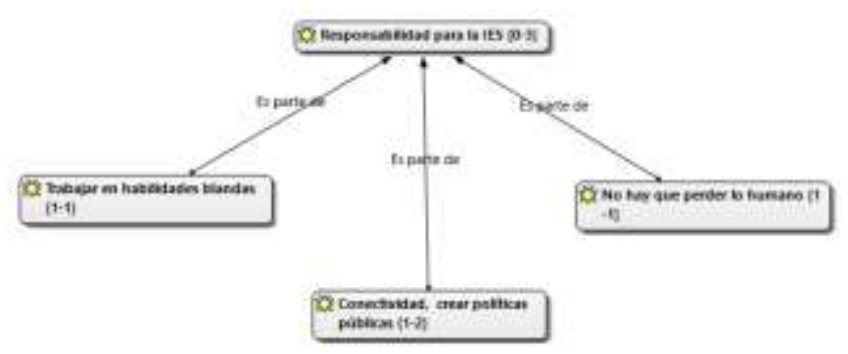

Authors 2020.

\section{Conclusions and Discussion.}

As conclusions, it is worth to emphasize that both USR and ESR are trends that contribute to companies and universities in such a way that they have tools that are very similar for the two units of analysis such as: People, both in the company (collaborators) and in the University (teachers) are a fundamental part of their development. Likewise, care for the environment is another factor they have in common, making environmental awareness part of the work of the company and the university.

Finally, quality is the common element between the two units of analysis, for both institutions quality becomes a determining factor in continuing to work towards human talent, this being the point where the two areas of analysis converge. 9. It is important to highlight that for the two units 
of analysis and for that matter, it is through their collaborators that they endure over time and are recognized for their good practices with their internal clients; it is necessary for companies to maintain the satisfaction of their collaborators through equitable remuneration, supportive working conditions, mentally stimulating work and supportive colleagues.

Thus, employees can have a positive impact on results; the organization improves the quality and efficiency of work, favors the exchange of information, generates a greater capacity for learning within the organization and the possibility of using new knowledge, and optimizes resources and technologies. 6

\section{References}

[1] Elkington, John. (1999). Cannibals with forks: the triple bottom line of 21 st century business. New Society Publishers.

[2] Friedman, M. (1984). CurrencyCompetition: A Skeptical View. En P. Salin (comp.). Currency . Competition and Monetary Union. (pp. 42-46). La Haya: MartinusNijhoff.

[3] Freeman E (2005). La Ética Consiste en hacer cosas por los demás y por uno mismo. Compromiso Empresarial. https://www.compromisoempresarial.com/rsc/2005/09/edward-freemanla-etica-consiste-en-hacer-cosas-por-los-demas-y-por-uno-mismo/

[4]Friedman (1970) «La responsabilidad social de los empresarios es aumentar sus ganancias.» revisa del New York Time

https://masteradmon.files.wordpress.com/2013/10/4_friedman-1970-laresponsabilidad-social-de-los-negocios-1.pdf.

[5] Galeano María (2004) Diseño de proyectos en investigación cualitativa, Colombia, grupo editorial Universidad EAFIT.

[6] Lombana, M, Restrepo, S (2018), "El endomarketing factor clave para la innovación organizacional. "Las personas como gestores de cambio". Revista Electrónica Ide@s CONCYTEG con ISSN: 2007-2716, Recuperado de https://sices.guanajuato.gob.mx/resources/ideas/ebooks/208/descargas.pdf, Consultado el 30 de agosto de 2020

[7]Mineducación: Recuperado de.

https://www.mineducacion.gov.co/portal/Educacion-superior/ProyectosCalidad/307592:Evaluacion-certificacion-y-acreditacion . Consultado el 30 de agosto de 2020

[8]Porter, Michael E., and Mark R. Kramer. "Strategy and Society: The Link between Competitive Advantage and Corporate Social
Responsibility." Harvard Business Review 84, no. 12 (December 2006): 78-92.

[9]Robbins, Stephen (2004). Comportamiento Organizacional, México, Pearson Education.

[10] UNESCO (2002) Claves para el siglo XXI, Barcelona: Ediciones Unesco, Editorial Crítica. Pág. 266. 